REVIEW ARTICLE

\title{
Regular Exercise, Thombocyte, Collagen and Breast Cancer
}

\author{
TONGUÇ VARDAR ${ }^{1}$, IBRAHIM KUBILAY TÜRKAY² \\ ${ }^{1}$ Faculty of Physical Education and Sports Science, Uludag University, Turkey \\ ${ }^{2}$ Süleyman Demirel University, Faculty of Sport Sciences, Isparta/TURKEY \\ Correspondence to Dr. Tonguç Vardar, Email. tongucvardar@uludag.edu.tr Cell: +90 5062888240
}

\begin{abstract}
Platelets, which play a very important role in the continuation of vital activities, play an important role in blood coagulation. Various chronic diseases can reduce the platelets produced by our body below the standard level or increase them in a dangerous way. Diseases related to malignancy, that is, malignant tumors, come at the beginning of the diseases that disrupt the platelet balance. One of them is breast cancer. Breast cancer is a type of cancer that occurs as a result of mutations in the BRCA1 (17q21) and P53 (17p13) genes located on the 17th chromosome and the BRCA2 gene located on the 13th chromosome. It is known that the amount of bone mass due to estrogen hormone is closely related to the formation of breast cancer. Collagen is the protein that forms bones, cartilage fibers and joints, which are the building blocks of our motor (movement) system. The main protein that forms the main structure of the bone is Type I collagen and about 30 types of collagen have been defined. It acts as a support for bone and cartilage tissue. Regular exercise, on the other hand, is a type of regular, systematic and programmed physical activity done with the aim of improving the physical and mental state of the person. There are many studies that found that exercise increases the tendency of platelet aggregation (aggregation, aggregation, aggregation). In addition, there are scientific studies that show that regular exercise and regularly used collagen stop the progression of breast cancer.

The aim of this scientific review is to describe the relationship between platelet, collagen, breast cancer and regular exercise.
\end{abstract}

Keywords: Quiet eye, Platelet, Collagen, Breast Cancer, Regular exercise

\section{INTRODUCTION}

\section{THROMBOCYTE (PLT)}

Platelets, also called platelets, are cells that enable blood to clot in our body. In blood measurements, platelets are called "PLT". The ideal platelet count in the human body (in a healthy person) is considered to be between 150-450 thousand microliters. Kidney failure, liver failure, thyroid diseases, connective tissue diseases, myeloproliferative diseases, myelodysplastic syndrome, malignancies and cardiovascular diseases can disrupt the platelet balance in our body. . They are approximately 10-15 times larger than erythrocytes (red blood cells). While the color of the cytoplasm (cell fluid) is blue until the platelet is produced, the color changes to red as soon as the platelet is produced. (2) In thrombocytopenia (the condition where the platelet count is below normal), the detection of the presence of megakaryocytes can be a guide when the cause cannot be determined. While low or no megakaryocytes may indicate a functional disorder in the bone marrow, it can be said that the high number of megakaryocytes tries to prevent the destruction of peripheral vascular diseases (peripheral). ${ }^{(1)}$

Reasons That Lower The Thrombocyte LeveL

$>\quad$ Side effects of some drugs used

$>\quad$ Bone marrow failure (Aplastic anemia)

$>\quad$ B12 and folic acid deficiency

$>$ Pregnancy (blood fluid increases and blood becomes thinner)

$>$ Blood transfusion

$>\quad$ Viral diseases (Chickenpox, HIV, EBV)

$>$ Immune system diseases (idiopathic thrombocytopenic purpura, rheumatological disorders)

> Hypersplenism (overwork of the spleen)
$>$ Poisoning and radiation

$>\quad$ Long-term consumption of alcohol

$>$ Cancer of the blood

$>$ Bone marrow diseases

$>\quad$ Some chronic diseases $(1,21,22)$

Reasons That Rise Throttle Levels

$>\quad$ Lack of iron in the body

$>$ Spleen deficiency

$>$ Erythrocyte deficiency due to bleeding

$>\quad$ Bone marrow cancers

$>$ Physiological overproduction of the body $(23,26)$

\section{COLLAGEN}

Collagen is the protein that forms bones, cartilage fibers and joints, which are the building blocks of our motor (movement) system. Nearly 30 types of collagen have been defined and named as type I and type II. The main protein that forms the main structure of the bone is Type I collagen. (17) The main reason why collagen is named in this way is its molecular structure. The main molecule of collagen is tropocollagen. Tropocollagens are also made up of procollagens produced inside the cell. (3)

It allows the cells to stay together. It also prevents the cell from moving to another area and preventing microorganisms from reaching the cell. It is the main component of connective tissue. It contains carbohydrates. It has a triple helix (coiling of three peptide chains) structure. Collagens make up $25 \%$, ie $1 / 3$ of the total proteins in our body. (18) They are found in bone, tendon, skin, blood vessels and cornea. In the deficiency of ascorbic acid, that is, vitamin C, collagen production is impaired and scurvy occurs. Subcutaneous bleeding, gingival bleeding and wound healing are delayed. (4) If collagen is boiled with water and dilute acid, it turns into gelatin. (4). Type I collagen in bone has the capacity to be mineralized. ${ }^{(6)}$ The cells responsible for bone 
formation, bone matrix synthesis, secretion and mineralization are osteoblasts. The substance that acts as a support in bone and cartilage tissue is collagen. (5) With the decrease in the synthesis of collagen, which is an important protein and amino acid source, symptoms such as delayed healing of wounds, fatigue and poor performance are also observed. FDA, which is accepted as a competent authority, has been declared as generally safe $(8,9)$ GRAS (Generally Recognized As Safe) by EFSA and does not carry any allergen risk. According to the Turkish Food Codex communiqué on fortifying foods, the use of collagen hydrolyzate in foods is appropriate. (10) The daily dose recommended by Moskowitz is stated as 10 grams. (11,12) According to some of the scientific studies, the effectiveness of collagen hydrolyzate is increased if enriched with vitamin C. ${ }^{(13)}$

\section{BREAST CANCER}

Breast cancer is a type of cancer that occurs as a result of mutations in the BRCA1 (17q21) and P53 (17p13) genes located on the 17th chromosome and the BRCA2 gene located on the 13th chromosome. The gene in the male type is the androgen receptor gene located on the Y chromosome.

\section{Breast Cancer Causes}

$>\quad$ Familial factors (genetic inheritance): Presence in mother, daughter or sister

$>$ Radiation

$>$ Viral

$>$ Hormones and Nutrients (Excessive consumption of fat and sugar)

$>$ Estrogen

$>$ High Prolactin. ${ }^{(34,35)}$

In women who have not given birth or who have given birth for the first time after the age of 31 , the risk of developing breast cancer is 3-4 times higher than women who have given birth for the first time before the age of $18(34,35)$.

It has been proven in scientific studies that there is a close relationship between the amount of bone mass due to estrogen hormone, especially in the formation of breast cancer. ${ }^{(14,15,16)}$ Osteocalcin, namely Bone GLA Protein (BGP), is a "Gamma Carboxy Glutamic" with the destruction of amino acids of some proteins in the bone by enzymes related to vitamin K. acid (GLA)" format. As a result of this transformation, the modified amino acid increases the $\mathrm{Ca} 2+$ binding ability of proteins. ${ }^{(18)}$

\section{Breast Cancer Types}

$>$ Ductal adenocarcinoma: The type that occurs in one breast. Its incidence is approximately $78 \%$.

$>$ Lobilar carcinoma: It is a bilateral formation. Its incidence is approximately $9 \%$.

$>\quad$ Benign prognoses $(10 \%$

$>$ Comedocarcinomas (5\%)

$>\quad$ Medullary carcinoma (4\%)

$>$ Colloid carcinoma $(3 \%)$

$>$ Inflammatory carcinoma (1\%)

$>\quad$ Paget's Disease of the Breast(34)

Spread of Breast Cancer to the Body

The spread of breast cancer to the body (metastasis) happens in two ways. They spread through the lymph nodes or through the blood. The organs that metastasize most frequently are bone, skin, liver, lung, brain and lymph nodes. Bone involvement is observed during the spread of the disease to the body or during its progression. ${ }^{(36)}$

\section{REGULAR EXERCISE}

Physical activity is the energy expenditure that we do as a result of our daily routine and the movement of our appendages. Regular exercise, on the other hand, is a type of regular, systematic and programmed physical activity performed with the aim of improving the physical and mental state of the person. $(32,33)$

There are many studies that determined that exercise increases the tendency of aggregation (aggregation, aggregation, aggregation) in platelets. ${ }^{(21,22,23,29,30,31)}$ Gelatin enriched with vitamin $\mathrm{C}$ and Hydrolysis Collagen (HC) supplementation 1 hour before exercise ${ }^{(19)}$ In studies, it has been determined that there are short-term temporary increases in peripheral platelet count in one-time upper limit exercises and long-term lower-paced exercises. $(20,21,22,23,24,25)$ It has been suggested that this increase in platelet count may occur as a result of the incorporation of storage platelets in the spleen into the circulation. ${ }^{(24,26)}$ Warlow et al. found that when they induced the blood samples taken immediately after exercise with collagen one hour later, platelet aggregation did not change, but when they made the evaluation two hours later, the aggregation accelerated. . When they induced platelet aggregation with ADP and adrenaline, they observed an increase in aggregation rate both in the first and second hours. (27) In the presented study, blood samples were evaluated within 60 minutes after they were taken from the subjects. It was determined that the tendency to aggregation increased with exercise using ADP and collagen for platelet activation. It was determined that the tendency to aggregation increased with exercise using at rest and after exercise.

\section{CONCLUSION}

As a result, there are many studies that found that exercise increases the tendency of platelet aggregation (aggregation, aggregation, aggregation). In addition, there are scientific studies that show that regular exercise and regularly used collagen stop the progression of breast cancer.

Disclaimer: None.

Conflict of interest: None.

Source of funding: None

\section{REFERENCES}

1. Kaptan, K. (2007). Trombosit Hastalıklarında Temel Tanısal Yaklaşım. 5. İlk Basamak Kursu. Gülhane Askeri Tıp Akademisi, Ankara

2. http://hematolojiatlasi.com/atlas_content.php?id=70

3. https://tr.wikipedia.org/wiki/Kollajen

4. http://en.wikipedia.org./wiki/Collagen\#/media/File: Collagen_biosynthesis_(en).png

5. Djavani, M., Kirkali, B.G., Güner, G. (1991). Amino acid composition of elastin purified from bovine human aortas. American Journal of Medical and Medical Sciences 19: 545.

6. Andrianarivo, A.G., Robinson, J.A., Mann, K.G., Tracy, R.P. (1992). Growth on type I collagen promotes expression of the osteoblastic phenotype in human osteosarcoma MG-63 cells. Journal of Cellular Physiology 153: 256-265.

7. Sağcan, A., Omay, S., Akın, M. (2011). Kronik Sigara İçen Koroner Arter Hastalarında Agonistlerle İndüklenmiş İn-Vitro 
Trombosit Agresyon Yanıtı. Türk Kardiyoloji Derneği Araştırma Merkezi, 29: 488-492p.

8. European Food Safety Authority (EFSA). (2011). EFSA Panel on Dietetic Products, Nutrition and Allergies. Scientific Opinion on the substantiation of a health claim related to collagen hydrolysate and maintenance of joints pursuant to Article 13(5) of Regulation (EC) No 1924/20061. EFSA Journal 9(7): 2291.

9. U.S. Food and Drug Administration (FDA). (1997). The Sourcing and Processing of Gelatin to Reduce the Potential Risk Posed by Bovine Spongiform Encephalopathy (BSE) in FDA-Regulated Products for Human Use. Docket No: 97D-0411.

10. Anonymous. (2014). Türk Gıda Kodeksi Gıda Katkı Maddeleri Yönetmeliği (2014/29185). http :// www .tarim .gov.tr / Mevzuat/Turk-Gida-Kodeksi. (Erişim tarihi: 24.11.2014).

11. Bruyère, O., Zegels, B., Leonori, L., Rabenda, V., Janssen, A., Bourges, C., Reginster, J.Y. (2012). Effect of collagen hydrolysate in articular pain: a 6- month randomized, double-blind, placebo controlled study. Complementary Therapies in Medicine 20: 124-130.

12. Schauss, A.G., Stenehjem, J., Park, J., Endres, J.R., Clewell, A. (2012). Effect of the novel low molecular weight hydrolyzed chicken sternal cartilage extract, BioCell Collagen, on improving osteoarthritis-related symptoms: a randomized, double-blind, placebocontrolled trial. Journal of Agriculture and Food Chemical 60(16): 4096-101.

13. Ersus Bilek, S., Kaya Bayram, S. (2015). Kolajen Hidrolizatının Fonksiyonel Bir Bileşen Olarak Gıda Endüstrisinde Kullanıması. Akademik Gıda. 13(4) 327334. ISSN Print: 1304-7582, Online: 2148-015X.Izmir.

14. Cauley, J.A., Lucas, F.L., Kuller, L.H., Vogt, M.T., Browner, W.S., Cummings, S.R. (1996). Bone minneral density and risk of breast cancer in older women. JAMA 276:1404-1406.

15. OBrien, K., Caballero, B. (1997). High Bone Mass as a Marker for Breast Cancer Risk. Nutrition Review. 55: 284-286.

16. Zhang, Y., Kiel, D.P., Kreger, B.E., Cuppless, L.A., Ellison, R.C., Dorgan, J.F., Schatzkın, A., Levy, D., Felson, D.T. (1997). Bone mass and risk of breast cancer among postmenopausal women. N Engl J Med 336:61167.

17. Blomqvist, C., Risteli, L., Risteli, J., Virkkunen, P., Sarna, S., Elomaa, I. (1996). Markers of type I collagen degradation and synthesis in the monitoring of treatment response in bone metastases from breast carcinoma. $\mathrm{Br}$ J Cancer 73: 1074-1079.

18. Özbek Kır, Z. (1999). Meme Kanserinde Kemiğe Metastaz Durumunun Belirlenmesinde Bazı Osteoblastik/Osteoklastik Biyokimyasal Göstergelerin Ve Serum Prolidaz Aktivitesinin Tanısal Değeri. Uzmanlık Tezi. İstanbul Tıp Fakültesi Biyokimya Ana Bilim Dalı. T.C. Yüksek Öğretim Kurulu Dökümantasyon Merkezi. 88307.

19. Dana Lis, M., Baar, Keith. (2019). Effects of Different Vitamin C-Enriched Collagen Derivatives on Collagen Synthesis. Int J Sport Nutr Exerc Metab. Sep 1;29(5):526-531. doi: 10.1123/ijsnem.2018-0385.

20. De Scalzi, M., Cinelli, P., De Leonardis, V., Becucci, A.,
Mariani, R., Fattirolli, F., Ciapini, A. (1987). Response of some haemacoagulatory and haemarheological variables to maximal exercise in sedentary and active subjects.J Int Med Res 15: 361-367.

21. Chen, H., Tang, Y., Jen, C.J. (1989). Effect of acute exercise on bleeding time, bleeding amount and blood cell counts: A comparative study. Thromb Res 55:503-510.

22. Dimitriadou, C., Dessypris, A., Louizou, C., Mandalaki, T., (1977). Marathon run II:Effects on platelet aggregation. Thromb Haemostas 37: 451-455.

23. Hendra, T.J., Oughton, J., Smith, C.C.T., Betteridge, D. J., Yudkin, J.S. (1988). Exercise-induced changes in platelet aggregation: A comparison of whole blood and platelet rich plasma techniques. Thromb Res 52: 443-451.

24. Sinsinger, H., Fitscha, P. (1986). Jogging causes a significant increase in platelet sensitivity to PG 12. Int. J Sports Med 7: 338-341.

25. Winther, K., Trap-Jensen, J. (1988). The effect of exercise on platelet $\beta$ adrenoceptor function and platelet aggregation in healthy human volunteers. Clin Physiol 8: 147 - 153.

26. Chamberiain, R. G., Tang, M., Penington, D. G. (1990). Properties of the Exchange bisplenic platelets released into the circulation during exercise-induced thrombocytosis. Am J Hematol 34: 161-168.

27. Vulpian, E.F.A. (1873). Comment on Ranvier C. R. Soc. Biol., 5: 49.

28. Uçan, İ. (2018). Aerobik Egzersizin Bazı Fiziksel ve Fizyolojik Parametreler Üzerine Etkisinin İncelenmesi. Kilis 7 Aralık Üniversitesi Beden Eğitimi ve Spor Bilimleri Dergisi, 2 (1), 46-55. Retrieved from https:// dergipark. Orgtr / tr/ pub/ besbid/ issue / $34890 / 442706$.

29. Furui, H., Taniguchi, N., Yamouchi, K., Sotobata, I., Saito, H., Inagaki, H. (1986). Effects of treadmill exercise on platelet function, blood coagulation and fibrinolytic activities in patients with atrial fibrillation. Jpn Heart J 28 (2): 177-184.

30. Ohri, V.C., Chatter, J.C., Das, B.K., Akhtar, M., Tewari, S.C., Bhattacharji, P., Behl, A. (1983). Effect of submaximal exercise on haematocrit, platelet count, platelet aggregation and blood fibrinogen levels. J Sports Med 23(2): 127-130.

31. Piret, A., Niset, G., Despiesse, E., Wyns, W., Boeynaems, J., Poortmans, J., Degre, S. (1990). Increased platelet aggregability and prostacyclin biosynthesis induced by intense physical exercise. Thromb Res 57: 685-695.

32. Artış, A.S. (2009). Akut Yoğun Egzersizde Proinflamatuar Sitokinler ve Beyin Natriüretik Peptid (Bnp) Seviyesi İlişkisi, (Yayınlanmamış Uzmanlık Tezi), Erciyes Üniversitesi Tıp Fakültesi Fizyoloji Anabilim Dalı, Kayseri- 102; 3, 5, 16, 17, 60.

33. Türkay, İ.K. ve Atay, E. (2019). Düzenli Egzersizle Birlikte Kullanılan L-Carnitine'nin Genç Obez Ratların Kilo Vermelerine Etkisi [The Effect Of LCarnitine Used With Regular Exercise On Young Obez Rats Weight], Spor Eğitim Dergisi, 3 (1), 93-99.

34. Haskel, C.M., Casciato, D.A. (1995). Breast Cancer. "Manual of Oncology" 3Ed Chap. 10 s. 183-199, Lowitz B (ed) Little Brown, USA.

35. Rosai, J. (1996). Breast "Ackerman's Surgical Pathology", 8. Ed. Vol. 2. Chap. 20 s. 1565-1660, Mosby, St. Louis.

36. Stoll, B.A. (1983). Natural history, prognosis and staging of bone metastases. "Bone metastases monitoring and treatment." s120, Stoll BA, Parbho S (eds) New York, NY Raven Press. 